\title{
Study of the Molecular Mechanism of Decreased Liver Synthesis of Albumin in Inflammation
}

\author{
H. J. Moshage, J. A. M. Janssen, J. H. Franssen, J. C. M. Hafkenscheid, ${ }^{\star}$ and S. H. Yap \\ Division of Gastrointestinal and Liver Diseases, and *Division of Clinical Chemistry, Department of Medicine, St. Radboud University \\ Hospital, Nijmegen, The Netherlands
}

\begin{abstract}
Hypoalbuminemia in inflammatory disorders is not an infrequent finding. However, little is known about albumin synthesis in these patients. In the present study we have measured the albumin synthesis in four patients with inflammatory diseases using the $\left[{ }^{14} \mathrm{C}\right]$ carbonate technique. Because inflammation causes a decreased albumin synthesis and this decreased synthesis could not be related to a reduced amino acid supply, we have also examined the possible molecular mechanisms of reduced albumin synthesis during inflammation using in vivo and in vitro experiments in rats. In rats with turpentine-induced inflammation, serum albumin concentration and liver albumin mRNA level were markedly decreased. These changes could not be reproduced by administration of fibrinogen-, or fibrin-degradation products, or several hormones, such as corticosteroids, growth hormone, and adrenaline. However, monocytic products, especially interleukin 1 , postulated to be important mediators of the inflammatory response, reduced albumin synthesis and liver albumin messenger RNA content but not total protein synthesis in rats in vivo and in primary cultures of rat hepatocytes. These findings suggest that monocytic products play an important role in reduced albumin synthesis during inflammation.
\end{abstract}

\section{Introduction}

Albumin is the most abundant serum protein produced by the liver. In clinical practice the serum level of albumin continues to serve as an important marker for the presence, progress, or improvement of many diseases, even though it is the complex end result of synthesis, degradation or loss, and distribution between intra- and extravascular space.

Hypoalbuminemia in patients with inflammatory diseases such as pneumonia, rheumatoid arthritis, and severe bacterial infection is not an infrequent finding (1). Although it has been suggested that increased degradation of albumin is the primary cause of hypoalbuminemia, little is known about albumin synthesis in such patients. The purpose of this study was to investigate the albumin synthesis as determined by $\left[{ }^{14} \mathrm{C}\right]$ carbonate technique in patients with inflammatory disorders. Because the results indicate that an inflammatory reaction could lead to a

Address correspondence to Dr. S. H. Yap, Division of Gastrointestinal and Liver Diseases, Department of Medicine, St. Radboud University Hospital, 6500 HB Nijmegen, The Netherlands.

Received for publication 12 June 1986 and in revised form 30 January 1987.

J. Clin. Invest.

(c) The American Society for Clinical Investigation, Inc.

0021-9738/87/06/1635/07 \$1.00

Volume 79, June 1987, 1635-1641 decreased albumin synthesis and no signs of diminished supply of amino acids to the liver were found as an explanation of the reduction, we have examined the possible molecular mechanism of the decreased albumin synthesis during the inflammation using in vivo and in vitro experiments in rats.

\section{Methods}

Patients. Age, sex, and diagnosis of the four patients studied are demonstrated in Table I. All patients had a severe or moderate hypoalbuminemia. The control group was composed of 20 individuals, 17 males and 3 females, their ages ranging from 26 to $68 \mathrm{yr}$. They all had normal serum albumin level and normal liver "function" tests.

Amino acid analysis. Concentrations of serum amino acids were estimated using a Beckmann Unichrome (München, FRG) amino acid analyzer. After precipitation of the proteins ( $50 \mathrm{mg}$ sulphosalicylic acid was added to $1 \mathrm{ml}$ serum) and centrifugation, $0.5 \mathrm{ml}$ of the supernatant was used for analysis. The accuracy of the tryptophan determination on the amino acid analyser has been tested by adding different amounts of tryptophan $(40-250 \mu \mathrm{M})$ to a serum sample that had been dialyzed previously. After precipitation of the proteins the samples were analyzed for tryptophan content. The mean recovery of the added tryptophan was $89.2 \%$ (2).

Determination of plasma volume and albumin synthesis rate. The plasma volume was determined with ${ }^{131}$ I-labeled albumin just before the determination of the rate of albumin synthesis. ${ }^{131} \mathrm{I}$-labeled albumin was prepared according to the method described by McFarlane (3) with slight modification. The disappearance rate of ${ }^{131}$ I-labeled albumin was also determined $7 \mathrm{~h}$ after injection of ${ }^{131}$ I-labeled albumin.

Rate of albumin synthesis was measured by the $\left[{ }^{14} \mathrm{C}\right]$ carbonate method of McFarlane (4), as modified and described by Hafkenscheid et al. (5).

Patients had a regular hospital diet $(\sim 60 \mathrm{~g}$ protein, $60 \mathrm{~g}$ fat, and $250 \mathrm{~g}$ carbohydrate), all of which was consumed in the period of investigation. The thyroid gland was blocked with lugol solution, starting 2 $\mathrm{d}$ before the determination. In the morning of the investigation, blood samples were collected for the measurement of serum or blood level of hemoglobin, hematocrit, albumin, amino acids, creatinine, urea, transaminases, alkaline phosphatase, and leucine amino peptidase. Patients were not treated with oral antibiotics or chemotherapeutics to reduce the bacterial urease activity in the intestine. A 50-ml blood sample was collected $7 \mathrm{~h}$ after i.v. injection of $100-200 \mu \mathrm{Ci} \mathrm{Na}{ }_{2}{ }^{14} \mathrm{CO}_{3}$ for the measurement of the specific activity of the $\left[{ }^{14} \mathrm{C}\right]$ guanidine group of arginine in albumin. An additional 8-ml blood sample was obtained at the same time for the measurement of the specific activity of the endogenously formed $\left[{ }^{14} \mathrm{C}\right]$ urea.

$1 \mathrm{~d}$ later, $5-10 \mu \mathrm{Ci}\left[{ }^{14} \mathrm{C}\right]$ urea was injected i.v. for the determination of the disappearance rate of urea (5).

$15 \mathrm{ml}$ plasma was saturated to $50 \%$ with $\left(\mathrm{NH}_{4}\right)_{2} \mathrm{SO}_{4}$ for the isolation of albumin. The precipitate was separated by centrifugation, $30,000 \mathrm{~g}$ for $20 \mathrm{~min}$. The supernatant was adjusted to $\mathrm{pH} 4.5$ by slowly adding 1 $\mathrm{M} \mathrm{HCl}$, and the albumin thus precipitated was collected by centrifugation. After redissolving the albumin precipitate in $10 \mathrm{ml}$ of water and adjusting to $\mathrm{pH} 7.0$ with $1 \mathrm{M} \mathrm{NaOH}$, the entire procedure was repeated. The albumin fraction, $25 \mathrm{ml}$, was dialyzed overnight. The purity of the albumin preparation, determined by electrophoresis on cellulose acetate, 
Table I. Age, Sex, Diagnosis, Serum Albumin Concentration, and Liver Enzyme Tests in Four Patients with an Inflammatory Disease

\begin{tabular}{lllllrrr}
\hline Patient & Age & Sex & Diagnosis & Serum albumin & ASAT & ALAT & Alkaline phosphate \\
\hline & $y r$ & & & g/liter & U/liter & U/liter & U/liter \\
1 & 69 & F & Acute pyelocystitis & 29.3 & 4 & 6 & 69 \\
2 & 57 & M & Periappendicular abscess & 29.1 & 13 & 28 & 168 \\
3 & 23 & F & Endocarditis lenta & 25.8 & 19 & 30 & 54 \\
4 & 65 & M & Pulmonary embolism & 31.2 & 6 & 11 & 112 \\
Control value & & & $44-55$ & $<15$ & $<15$ & $<120$ \\
\hline
\end{tabular}

was $97 \%$. After an adapted dilution the albumin was hydrolyzed, the arginine was isolated from the hydrolysate, and the specific activity of the guanidine group of the arginine was determined as described previously (5).

The calculation of the rate of albumin synthesis can be made using the precursor-product relationship. The $\left[{ }^{14} \mathrm{C}\right]$ arginine produced in the liver cell from $\left[{ }^{14} \mathrm{C}\right]$ carbonate is the common precursor for $\left[{ }^{14} \mathrm{C}\right]$ urea and $\left[{ }^{14} \mathrm{C}\right]$ guanidine of arginine in albumin. Under well-defined conditions the specific activity of all products of a single labeled precursor pool must be equal to that of the precursor (4). Specific activity of albumin from $t 1-t 0$ is then equal to specific activity of synthesized urea from $t 1-t 0$ : synthesized albumin $(t 1-t 0)=(\mathrm{sp}$ act of albumin at $t 0 / \mathrm{sp}$ act of urea at i0) $\times$ fractional synthesis rate of urea $\times$ plasma albumin pool. The specific activity of albumin is expressed as the activity of guanidine $C$ of arginine in albumin. The specific activity of serum albumin $7 \mathrm{~h}$ after i.v. injection of $100-200 \mu \mathrm{Ci} \mathrm{Na}{ }^{14} \mathrm{CO}_{3}$ ranged from 1.36 to $2.56 \mathrm{dpm}$ per $\mu \mathrm{mol}$ arginine and the specific activity of urea variêd from 11.25 to $30.4 \mathrm{dpm} /$ mmol urea. Because in this study the fractional synthesis of urea was measured $24 \mathrm{~h}$ after injection of $\mathrm{Na}_{2}{ }^{14} \mathrm{CO}_{3}$ by i.v. administration of 5$10 \mu \mathrm{Ci}\left[{ }^{14} \mathrm{C}\right]$ urea, it was important to maintain a steady state of urea and albumin metabolism in this period. Patients were given a constant diet at the same time in the $2 \mathrm{~d}$ of the experiment. Only patients and control individuals who had serum concentrations of albumin, urea, and urinary urea excretion at the same level in the $2 \mathrm{~d}$ of experiments were included in this study.

Laboratory methods. Transaminases, alkaline phosphatase, and leucine amino peptidase were determined according to routine laboratory methods.

Animals. Male Wistar rats weighing $180-200 \mathrm{~g}$ were used throughout and maintained on standard Purina chow and water ad lib. For the acute inflammatory reaction, rats were injected intramuscularly with $1.0 \mathrm{ml}$ of commercial turpentine.

Preparation of rat hepatocytes and primary culture. Liver cells were prepared according to the method of Seglen (6) with some modifications as described previously (7). All buffers were autoclaved before use and oxygenated by direct bubbling with oxygen. Collagenase buffer $(0.5 \mathrm{mg} /$ $\mathrm{ml}$ ) was supplemented with $0.05 \mathrm{mg} / \mathrm{ml}$ soybean trypsin inhibitor (7).

Cells were filtered, preincubated, and centrifuged in $\mathrm{Ca}^{2+}$ and $\mathrm{Mg}^{2+}$ free Hanks' balanced salt solution (HBSS) containing $2 \%$ bovine serum albumin (BSA). Damaged and nonparenchymal cells were removed. The cell suspension was then passed through a $100-\mu \mathrm{M}$ nylon filter and the viability of the hepatocytes was determined by trypan blue exclusion tests.

The culture medium was William's medium E supplemented with $5 \%$ (vol/vol) fetal calf serum (FCS), $2 \mathrm{mM}$ L-glutamine, $20 \mathrm{mU} / \mathrm{ml}$ porcine insulin, dexamethasone as indicated, $2.5 \mu \mathrm{g} / \mathrm{ml}$ fungizone, $50 \mu \mathrm{g} / \mathrm{ml} \mathrm{gen-}$ tamycine, and $100 \mu / \mathrm{ml}$ vancomycin. Hepatocytes were seeded at a concentration of $175 \times 10^{3}$ cells per $\mathrm{cm}^{2}$ in polystyrene flasks or dishes and maintained in a humidified atmosphere composed of $95 \%$ air and $5 \%$ $\mathrm{CO}_{2}$. The medium was renewed $2-4 \mathrm{~h}$ after cell seeding and every $24 \mathrm{~h}$ thereafter.

Incorporation of labeled precursor into protein. $\left[{ }^{3} \mathrm{H}\right]$ Leucine was added to the cell culture medium $(5 \mu \mathrm{Ci} / \mathrm{ml}) . \sim 50 \%$ of leucine present in the culture medium was radiolabeled (specific activity of $\left[{ }^{3} \mathrm{H}\right]$ leucine in medium is thus $\sim 60 \mathrm{Ci} / \mathrm{mmol}$ ). At the indicated times, duplicate $75-\mu \mathrm{l}$ samples were withdrawn from the medium. 10- $\mu$ l samples were diluted to $100 \mu \mathrm{l}$ in $0.1 \mathrm{~N} \mathrm{NaOH}$ and $1 \mathrm{ml} 10 \%$ trichloroacetic acid was added. Samples were heated for $20 \mathrm{~min}$ at $90^{\circ} \mathrm{C}$ and subsequently cooled on ice for $20 \mathrm{~min}$. Protein precipitates were collected on nitrocellulose filter discs and counted for radioactivity.

Immunoprecipitation of ${ }^{3} \mathrm{H}$-labeled albumin. Determination of ${ }^{3} \mathrm{H}$ labeled albumin in the culture medium was essentially performed as described previously (8). $25-\mu \mathrm{l}$ samples were diluted in $500 \mu \mathrm{l}$ buffer containing $10 \mathrm{mM}$ sodium phosphate, $\mathrm{pH} 7.2,150 \mathrm{mM} \mathrm{NaCl}, 1 \%$ Triton $\mathrm{X}-100,0.5 \%$ sodium deoxycholate, $0.1 \%$ sodium dodecyl sulfate (SDS), $5 \mathrm{mM}$ leucine, $0.1 \mathrm{mM}$ phenylmethylsulfonylfluoride, and $1 \mathrm{mM}$ EDTA and incubated with $1,000 \mathrm{dpm}\left[{ }^{14} \mathrm{C}\right]$ albumin as tracer for recovery, 20 $\mu \mathrm{g}$ albumin as carrier, and goat-anti-rat albumin $\gamma$-globulin. After 16 $h$ incubation at $4^{\circ} \mathrm{C}$, the mixture was layered over a $200-\mu l 10 \%$ (wt/wt) sucrose cushion and centrifuged for $5 \mathrm{~min}$ in an Eppendorf centrifuge. The pellet was washed three times, dissolved in $0.1 \mathrm{NaOH}$, and precipitated with $10 \%$ trichloroacetic acid, and collected on nitrocellulose filter paper discs for counting, using a double-labeling program. $\left[{ }^{14} \mathrm{C}\right]$ Albumin was prepared chemically from the purified protein with $\left[{ }^{14} \mathrm{C}\right]$ formaldehyde by reductive methylation as described by Crane and Miller (9).

DNA determination. Cells were suspended in water and sonicated. After centrifugation, DNA in supernatant was measured by a fluorometric technique as described by Kapùscinski and Skoczylas (10).

Preparation of liver and cell RNA. Total postnuclear RNA of liver tissue was prepared as described by Taylor and Schimke (11). Cytoplasmic RNA from hepatocytes in primary cultures was isolated according to the following procedure. Cell pellets were homogenized in a buffer containing $50 \mathrm{mM}$ Tris- $\mathrm{HCl}, \mathrm{pH} 7.4,25 \mathrm{mM} \mathrm{NaCl}, 5 \mathrm{mM} \mathrm{MgCl}_{2}, 0.25 \mathrm{M}$ sucrose and $0.3 \mathrm{mg} / \mathrm{ml}$ heparin. After addition of $1 / 10^{-\mathrm{vol}} 10 \%$ Triton X100 and centrifugation of the particulate material for $10 \mathrm{~min}$ at 16,000 $g$, RNA was extracted by addition of $1 / 2$-vol $0.3 \mathrm{M} \mathrm{NaCl}, 1.5 \%$ SDS, 15 mM EDTA, $30 \mathrm{mM}$ Tris- $\mathrm{HCl}, \mathrm{pH} 9.0$, and an equal volume of phenol/ chloroform/isoamylalcohol (50:48:2, vol/vol/vol). When no detectable interface remained, $2.5 \mathrm{vol}$ cold ethanol was added. RNA was precipitated overnight at $-20^{\circ} \mathrm{C}$ and isolated by centrifugation at $16,000 \mathrm{~g}$ for 20 $\min$ at $-5^{\circ} \mathrm{C}$.

Incorporation of labeled precursor into $R N A .61 \mathrm{mCi} / \mathrm{mmol}$ [6${ }^{14} \mathrm{C}$ ]orotic acid was added to $3 \mu \mathrm{Ci} / \mathrm{ml}$ cell culture medium. At the indicated times, cells of duplicate wells were washed and harvested with HBSS containing $0.1 \%$ Triton X-100. $1 \mathrm{ml}$ of ice-cold $20 \%$ trichloroacetic acid was added to $100-\mu 1$ samples and precipitates were collected on nitrocellulose filter paper discs and counted for radioactivity. Correction was made for incorporation of $\left[{ }^{14} \mathrm{C}\right]$ orotic acid into non-RNA by determining the incorporation in duplo samples treated for $30 \mathrm{~min}$ at $90^{\circ} \mathrm{C}$ in $10 \%$ trichloroacetic acid.

Preparation of purified albumin $\mathrm{mRNA}$ and ${ }^{3} \mathrm{H}$-labeled complementary DNA (cDNA). Purification of mRNA specific for rat albumin and the synthesis of the specific complementary DNA probe from this purified mRNA have been reported previously (12). Analytical RNA-cDNA hybridization was performed as described previously $(13,14)$. 
Preparation of monocytic products and specific antibodies against interleukin $1(I L-1) .^{1}$ The monocytic products were prepared by incubation of activated macrophages isolated from peritoneal exudates induced by glycogen in rabbits as described by Ritchie and Fuller (15). These preparations were endotoxin-free as tested by a Limulus test. The 15-kD-mol wt protein was purified from these monocytic products by G50-Sephadex chromatography and gel electrophoresis (16). This protein showed IL-1 activity as determined by the thymocyte proliferation assay (17). Specific antibodies against IL-1 were obtained from immunized goats using this purified $15-\mathrm{kD}-\mathrm{mol}$ wt protein as immunogen.

For comparison, in some studies we have used commercially available IL-1 obtained from activated human monocytes (ultra-pure human IL: 1, Genzyme Corp., Boston, MA).

Preparation of poly $A$ containing $R N A$. The poly A containing RNA was prepared from total RNA extracts by oligo (dT) cellulose chromatography (18) as described previously (11).

Cell-free protein synthesis and gel electrophoresis. The wheat germ extract was prepared as described by Marcu and Dudock (19). Radioactively labeled product synthesized in vitro was analyzed electrophoretically on $10 \%$ polyacrylamide/Na $\mathrm{DodSO}_{4}$ (SDS) slab gels (20). Dried slab gels were exposed to $\dot{x}$-ray film.

Materials. $\mathrm{Na}_{2}{ }^{14} \mathrm{CO}_{3},\left[{ }^{14} \mathrm{C}\right]$ urea, $\mathrm{L}-\left[4,5-{ }^{3} \mathrm{H}\right]$ leucine $(120 \mathrm{Ci} / \mathrm{mmol})$, $\left[6-{ }^{14} \mathrm{C}\right]$ orotic acid $(61 \mathrm{mCi} / \mathrm{mmol}),\left[{ }^{14} \mathrm{C}\right]$ formaldehyde $(17.6 \mathrm{mCi} / \mathrm{mol})$, and $\left[5-{ }^{3} \mathrm{H}\right] \mathrm{dCTP}(18.4 \mathrm{Ci} / \mathrm{mmol})$ were obtained from the Radiochemical Centre, Amersham International, Amersham, UK. ${ }^{131} \mathrm{I}$ as $\mathrm{Na}^{131} \mathrm{I}$ was from Hoechst A.G., Frankfurt, FRG. Collagenase type I, soybean trypsin inhibitor, oyster glycogen type III, BSA, heparin from porcine intestinal mucosa, dithiothreitol, and Hepes were purchased from Sigma Chemical Co., St. Louis, MO. William's medium E and FCS were from Flow Laboratories Inc., McLean, VA. Triton X-100 and SDS were obtained from BDH Chemicals Ltd., Dagenham, Essex, UK. Ribonuclease-free sucrose, EDTA, phenol, sodium deoxycholate, salts, and solvents were purchased from E. Merck, Darmstadt, FRG. Deoxyribonucleoside triphosphates were from Schwarz/Mann, Spring Valley, NY, and oligo(dT) 10 was from Collaborative Research, Inc., Waltham, MA. Avian myeloblastosis virus DNA-dependent RNA polymerase was kindly supplied by Dr. J. W. Beard, National Cancer Institute, Bethesda, MD. Nuclease S1 (Aspergillus oryzae) was purchased from Boehringer Mannheim GmBH, Mannheim, FRG, and stored at $2.510^{5} \mathrm{U} / \mathrm{ml}$ in $50 \%$ glycerol, $50 \mathrm{mM} \mathrm{NaCl}, 0.1 \mathrm{mM} \mathrm{ZnCl}_{2}$, and $20 \mathrm{mM}$ Tris- $\mathrm{HCl}, \mathrm{pH} 7.5$, at $-20^{\circ} \mathrm{C}$. Oradexon (dexamethasone disodium phosphate) was obtained from $\mathrm{Or}$ ganon, The Netherlands.

All glassware was sterilized and solutions were freshly prepared and autoclaved before use. BSA and soybean trypsin inhibitor were dialyzed against $0.15 \mathrm{M} \mathrm{NaCl}$ and, like all solutions used in the hepatocyte isolation and culturing, filtered through a $0.22-\mu \mathrm{M}$ Schleicher \& Schuell (Keene, $\mathrm{NH})$ filter and stored frozen.

\section{Results}

Table II demonstrates the plasma volume, intravascular albumin mass, and albumin synthesis rate of four patients with inflammatory disease. All patients had a low serum albumin level and a decreased intravascular albumin mass. Although the serum concentrations of amino acids in these patients were normal (Table III), the albumin synthesis was reduced ranging from 12.6 to $14.3 \mathrm{~g} / 24 \mathrm{~h}$ (mean value, $13.4 \mathrm{~g} / 24 \mathrm{~h}$ ). As compared with the control value, the result of albumin synthesis in these patients with inflammatory disease was significantly reduced with a $P$ value of 0.0036 (Wilcoxon two-sided tested). The liver "function" tests with the exception of patient No. 2 were all within normal limits.

For further studies to examine the molecular mechanism of

1. Abbreviation used in this paper: IL-1, interleukin 1. the reduction of albumin synthesis in inflammatory diseases, we have used an animal model of inflammation in rats injected intramuscularly with $1 \mathrm{ml}$ turpentine. Fig. 1 shows the SDSpolyacrylamide gel electrophoresis of wheat-germ cell-free reaction products under the direction of poly A containing RNAs prepared from livers of control rats and animals at intervals following turpentine injection. Despite the absence of changes in liver RNA content (data not shown, see also references 13 and 21) there was a decrease of translational activities of RNAs into albumin after turpentine administration. Quantitative analysis using the hybridization kinetics to measure the sequence content of albumin mRNA in different RNA fractions during the inflammatory reaction indicates that the concentration of albumin mRNA sequences in the liver was decreased to 35$50 \%$ of the control value (control value, $7.0 \%$ of total poly $A$ containing RNA). The variability of the control measurements, if repeated in paired animals sham-injected with saline over the same time course, was $100 \pm 9 \%$ (mean \pm SD). The time course of the changes of serum albumin concentrations and albumin mRNA levels in the liver is demonstrated in Fig. 2.

These changes of serum albumin concentration and liver albumin mRNA level could not be reproduced by administration of fibrinogen or fibrin degradation products and of several hormones such as corticosteroids, growth hormone, and adrenaline (data not shown). Because monocytic products, especially IL-1 (a 15-kD-mol wt protein in rabbits), have been suggested to play an important role in the physiological alterations that characterize the acute phase response such as fever, granulocytosis, and changes in the hepatic synthesis of the acute phase-associated proteins $(22,23)$, the following in vivo and in vitro experiments were performed to investigate the influence of these monocytic products including IL-1 on the albumin synthesis.

As shown in Fig. 3, the albumin mRNA concentration in the liver of rats injected intraperitoneally with monocytic products were decreased and comparable with the findings in rats treated with turpentine. In addition, concomitant administration of antisera (1 $\mathrm{ml}$ i.p.) against the $15-\mathrm{kD}$-mol wt protein of monocytic products partially abolished the effect of turpentine as well as the effect of monocytic products on the serum albumin level and on albumin mRNA content $(68 \pm 10 \%$ vs. $42 \pm 10 \%$ of control value for turpentine-treated rats).

Fig. 4 shows the effect of monocytic products on the $\left[{ }^{3} \mathrm{H}\right]$ leucine incorporated into the secreted albumin of primary cultures of rat hepatocytes. Because the specific activity of $\left[{ }^{3} \mathrm{H}\right]$ leucine in the culture medium was high, $\sim 50 \%$ of leucine present in the medium was radiolabeled $(60 \mathrm{Ci} / \mathrm{mmol})$, and the fact that $\left[{ }^{3} \mathrm{H}\right]$ leucine incorporated into secreted total protein was unchanged and the secreted $\left[{ }^{3} \mathrm{H}\right]$ fibrinogen was increased, the reduction of incorporation into the secreted albumin in the presence of IL-1 could not be ascribed to a reduced specific activity of leucine tRNA. The $\left[{ }^{3} \mathrm{H}\right]$ leucine incorporated into the secreted albumin was therefore the result of decreased albumin synthesis and secretion. The effects of monocytic products on the reduction of albumin synthesis and secretion in primary cultures of rat hepatocytes were more pronounced when $1 \mu \mathrm{M}$ dexamethasone was added to the culture medium. Concomitant with these findings, the albumin mRNA content was also lower in hepatocytes treated with the monocytic products than in control hepatocytes (Table IV). Nevertheless, the RNA synthesis of hepatocytes was not impaired by the addition of monocytic products in the culture medium (Fig. 5). The rate of albumin synthesis and secretion in hepatocytes cultured in the presence 
Table II. Plasma Volume, Intravascular Albumin Mass, and Albumin Synthesis Rate of Four Patients with an Inflammatory Disease

\begin{tabular}{|c|c|c|c|c|c|c|c|}
\hline \multirow[t]{2}{*}{ Patient } & \multirow{2}{*}{$\begin{array}{l}\text { Weight } \\
k g\end{array}$} & \multirow{2}{*}{ Height } & \multirow{2}{*}{$\begin{array}{l}\text { Plasma volume } \\
m l\end{array}$} & \multirow{2}{*}{$\begin{array}{l}\text { Intravascular albumin mass } \\
g\end{array}$} & \multirow{2}{*}{$\begin{array}{l}\text { Fractional synthesis rate* } \\
\% / d a y\end{array}$} & \multicolumn{2}{|c|}{ Albumin synthesis } \\
\hline & & & & & & $g / 24 h$ & $m g / k g / h$ \\
\hline 1 & 60 & 160 & 2,885 & 84.5 & 16.5 & 14.0 & 9.7 \\
\hline 2 & 66 & 168 & 3,048 & 88.7 & 16.8 & 14.3 & 9.0 \\
\hline 3 & 41.6 & 165 & 2,270 & 58.6 & 21.6 & 12.7 & 12.7 \\
\hline 4 & 71 & 172 & 3,300 & 103 & 12.2 & 12.6 & 7.4 \\
\hline \multicolumn{3}{|c|}{ Control value ( $n=20 ;$ mean \pm SD) } & $2,734 \pm 410$ & $136 \pm 20.7$ & $16.2 \pm 4.2$ & $21.9 \pm 6.6$ & $13 \pm 3.5$ \\
\hline
\end{tabular}

* Percent of intravascular albumin mass per day.

of commercially available IL-1 was also lower than in control experiments. Similar to the in vivo findings, addition of antisera against the $15-\mathrm{kD}-\mathrm{mol} \mathrm{wt}$ protein lead to a normalization of albumin synthesis and secretion in hepatocytes cultured in medium containing monocytic products $(430 \pm 60 \%$ vs. $240 \pm 40 \%$ of control value for hepatocytes cultured for $24 \mathrm{~h}$ in the presence of monocytic products without antiserum; see Fig. 4).

\section{Discussion}

If albumin metabolism is in a steady state, the rate of its synthesis will be equal to the catabolic rate. The estimation of albumin

Table III. Serum Concentrations* of Amino Acids in Three of Four Patients with Inflammatory Disease and Hypoalbuminemia

\begin{tabular}{lrrrr}
\hline Amino acid & $\begin{array}{l}\text { Patient } \\
2\end{array}$ & $\begin{array}{l}\text { Patient } \\
3\end{array}$ & $\begin{array}{l}\text { Patient } \\
4\end{array}$ & \multicolumn{1}{l}{$\begin{array}{l}\text { Control } \\
\text { value }\end{array}$} \\
\hline Essential & & & & \\
Threonine & 133 & 251 & 98 & $113 \pm 32$ \\
Valine & 202 & 389 & 303 & $227 \pm 42$ \\
Methionine & 23 & 53 & 22 & $27 \pm 9$ \\
Isoleucine & 80 & 114 & 88 & $84 \pm 21$ \\
Leucine & 129 & 220 & 159 & $141 \pm 33$ \\
Phenylalanine & 88 & 180 & 81 & $74 \pm 15$ \\
Lysine & 250 & 177 & 198 & $195 \pm 47$ \\
Tryptophan & 33 & 43 & 35 & $45 \pm 14$ \\
Total & 938 & 1,191 & 984 & $906 \pm 213$ \\
\hline Nonessential & & & & \\
Serine & 119 & 372 & 119 & $125 \pm 27$ \\
Proline & 196 & 344 & 182 & $247 \pm 92$ \\
Citrulline & 20 & 48 & 23 & $37 \pm 15$ \\
Glycine & 188 & 467 & 204 & $259 \pm 72$ \\
Alanine & 322 & 553 & 306 & $403 \pm 97$ \\
Tyrosine & 59 & 148 & 82 & $67 \pm 18$ \\
Ornithine & 59 & 106 & 109 & $101 \pm 30$ \\
Histidine & 128 & 95 & 53 & $88 \pm 21$ \\
Arginine & 129 & 61 & 132 & $123 \pm 34$ \\
Total & 1,220 & 2,194 & 1,210 & $1,450 \pm 406$ \\
& & & & \\
\hline & & & & \\
\hline
\end{tabular}

* In $\mu \mathrm{mol} /$ liter.

${ }^{\ddagger} n=20$; mean \pm SD. synthesis by the indirect method using radioactive iodine-labeled albumin has, however, certain limitations because of its long duration of measurement ( $\sim 2-3 \mathrm{wk})$ and the requirement for a steady state of albumin metabolism during that period. By using the $\left[{ }^{14} \mathrm{C}\right]$ carbonate method for the determination of albumin synthesis rate, a long period of steady-state metabolism is not required. The validity of this method for measuring albumin synthesis and the assessment of the possible radiation hazard involved in the study have been discussed previously (2, $5,24)$. Because a steady state of albumin metabolism in patients with acute inflammation cannot be achieved for a long period, albumin synthesis under these circumstances cannot be determined by the indirect method of radioactive iodine-labeled albumin.

In our present paper we report the albumin synthesis as determined by $\left[{ }^{14} \mathrm{C}\right]$ carbonate method in four patients with inflammatory disorders and severe hypoalbuminemia. Only patients and control subjects who had unchanged concentrations of serum albumin, urea, and urinary urea excretion at the same level in the period of experiments were included for this study. Although the albumin degradation was not determined in these patients, the measurements showed a decreased intravascular albumin mass and a reduction of albumin synthesis. A reduced rate of albumin synthesis can be the result of malnutrition, maldigestion, and/or malabsorption, or a severe diffuse liver disease

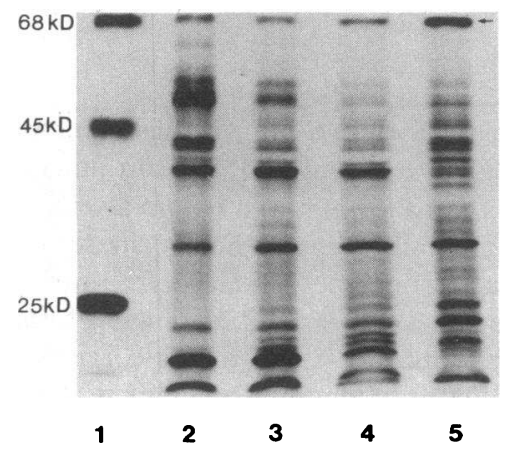

Figure 1. Autoradiograph of SDS-polyacrylamide gel electrophoresis of wheat germ translation products under the direction of liver mRNAs isolated from control rats and animals after turpentine injection. Lane $1,\left[{ }^{14} \mathrm{C}\right]-$ labeled marker proteins: albumin, 68-kD mol wt; ovalbumin, 45-kD mol wt; and chymotrypsin, 25-kD mol wt. Lane 2 , translation products directed by poly A-containing mRNA isolated from rat liver $24 \mathrm{~h}$ after injection of $1 \mathrm{ml}$ i.m. turpentine. Lane 3 , as indicated in lane $2,48 \mathrm{~h}$ after turpentine injection. Lane 4, as indicated in lane $2,72 \mathrm{~h}$ after injection. Lane 5, translation products directed by poly A-containing mRNA isolated from control rat liver. Arrow denotes position of albumin on gel. 


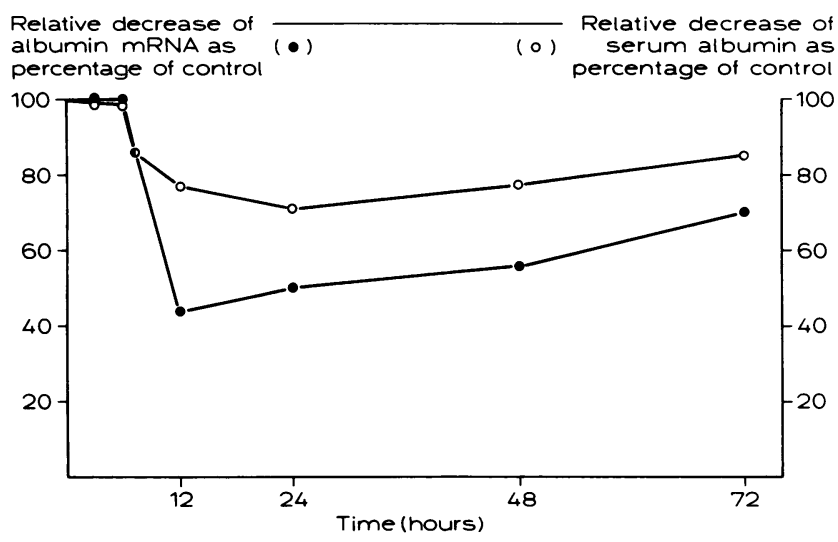

Figure 2. Time course of the changes in serum albumin concentrations and albumin mRNA levels in the liver during inflammation induced by administration of $1 \mathrm{ml}$ i.m. turpentine. Relative change in albumin mRNA levels was determined from hybridization data by comparison of the $\mathrm{R}_{0} t_{1 / 2}$ value of control poly A-containing RNA with the $R_{0} t_{1 / 2}$ values obtained from poly $A$-containing RNAs of rat livers at various time intervals after turpentine treatment. Serum albumin concentration was measured according to the routine laboratory method, with a control value of $30.1 \pm 2.0 \mathrm{mg} / \mathrm{ml}$. $\left(R_{0} t\right.$ is the product of initial RNA concentration in mole nucleotides per liter and time in seconds, given that A260 of 1.0 corresponds to $40 \mu \mathrm{g}$ RNA per ml. $\mathrm{R}_{0} t_{1 / 2}$ is $\mathrm{R}_{0} t$ value at $50 \%$ hybridization).

(1). Because clinical evidence of liver disease and intestinal abnormalities was absent in our patients and there were normal serum concentrations of amino acids, the reduction of albumin synthesis in our patients was most likely not due to a diminished supply of amino acids to the liver or the result of a primary liver disease.

To examine the possible molecular mechanism of decreased albumin synthesis in the liver during inflammation, we have therefore studied the liver content of albumin messenger RNA in rats and its translational activities in vitro using a wheat germ

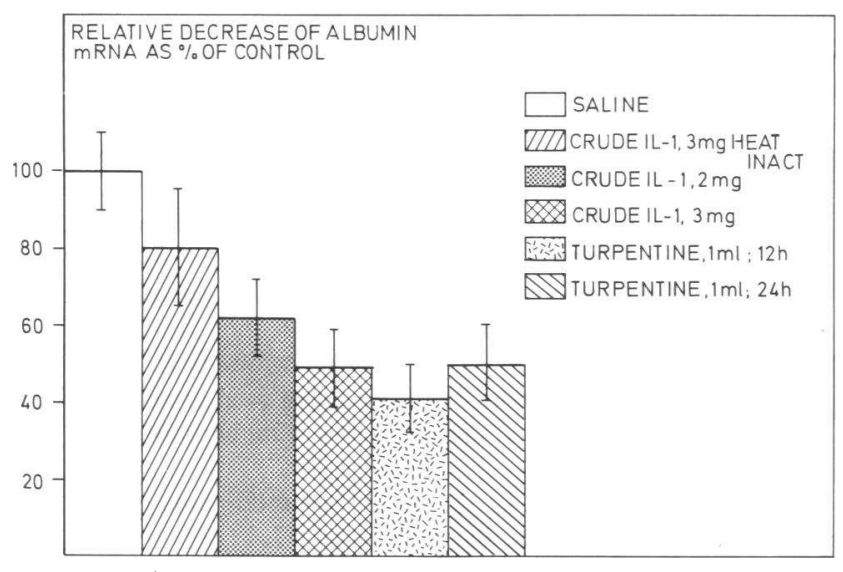

Figure 3. Relative levels of albumin mRNA in rat liver after treatment with saline (1 ml; i.p.), crude leucocytic extract (1-3 mg, $12 \mathrm{~h}$ after i.p. administration), and turpentine ( $1 \mathrm{ml}$ i.m., 12 and $24 \mathrm{~h}$ after administration). Values are expressed as percentages of controls (mean $\pm \mathrm{SD}, n$ $=4$ ) and were obtained from hybridization data as described in Fig. 2.

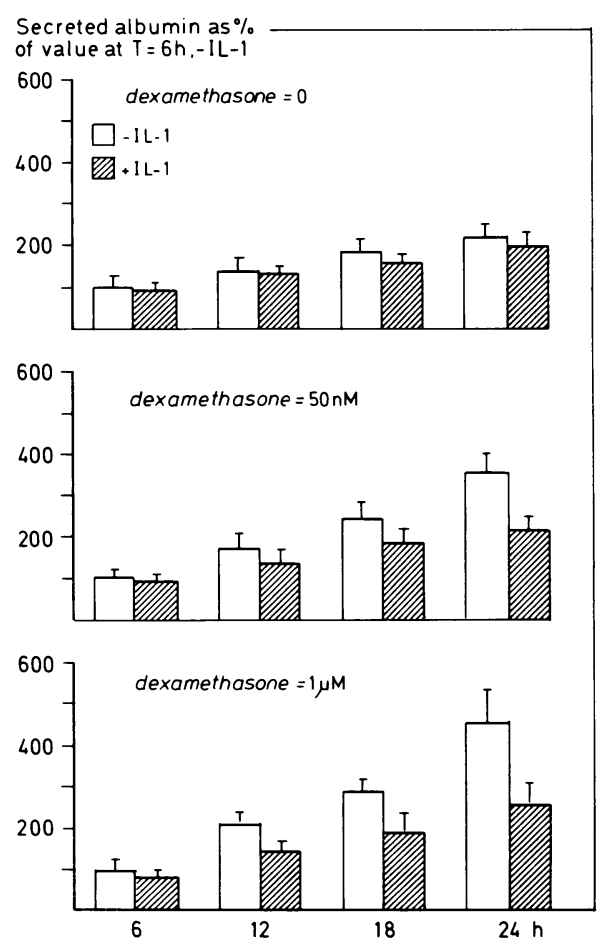

Figure 4. Secretion of albumin in primary cultures of rat hepatocytes into culture medium in absence of dexamethasone (upper panel) and in presence of $50 \mathrm{nM}$ (middle panel) and $1 \mu \mathrm{M}$ dexamethasone (lower panel). Results were obtained from determination of $\left[{ }^{3} \mathrm{H}\right]$ leucine incorporated into immunoprecipitable albumin per microgram cellular DNA and expressed as percentage of value obtained $6 \mathrm{~h}$ after adding $\left[{ }^{3} \mathrm{H}\right]$ leucine in the absence of IL-1. IL-1 was added as crude leukocytic extract ( $200 \mu \mathrm{g}$ per ml culture medium). Results are the means \pm SD of four experiments. Hepatocytes were cultured for $24 \mathrm{~h}$ with test substances before adding $\left[{ }^{3} \mathrm{H}\right]$ leucine.

cell-free translational system. The results indicate that during the inflammatory reaction after tissue injury, the decreased level of serum albumin is associated with a reduced concentration of albumin mRNA in the liver (Figs. 1 and 2). Because an inflammatory reaction does not lead to a decreased level of total liver RNA and the fibrinogen mRNA content and the fibrinogen synthesis were increased under this condition $(13,21)$, the decreased content of liver albumin mRNA is most likely regulated specifically by a different molecular process or mechanism.

Hypoalbuminemia and a decreased albumin synthesis during the acute phase response have been described previously, and

Table IV. Relative Level of Albumin mRNA in Hepatocytes Cultured for $48 \mathrm{~h}$ in Presence of $1 \mu M$

Dexamethasone With and Without Monocytic Products

\begin{tabular}{ll}
\hline Culture medium & $\begin{array}{l}\text { Relative level of } \\
\text { hepatocytic albumin mRNA }\end{array}$ \\
\hline Without IL-1 & $100 \%$ \\
With $200 \mu \mathrm{g} / \mathrm{ml} \mathrm{IL-1}$ & $49 \pm 10 \%$ \\
\hline
\end{tabular}

Mean \pm SD of four experiments. 


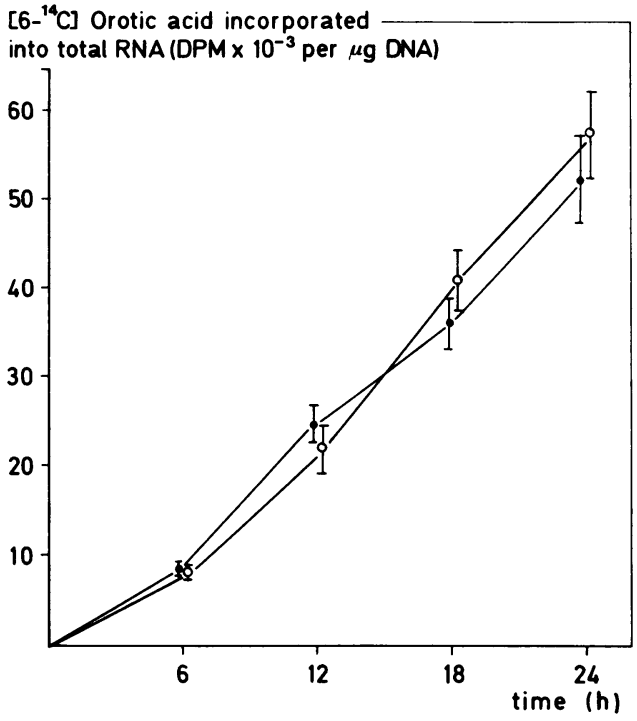

Figure 5. Incorporation of $\left[6-{ }^{14} \mathrm{C}\right]$ orotic acid into total RNA of hepatocytes in primary cultures in absence (open circles) and presence (closed circles) of IL-1 in culture medium. At the indicated times, cells were harvested and processed as described in Methods. IL-1 was added as crude leukocytic extract ( $200 \mu \mathrm{g}$ per ml culture medium). Results are the means \pm SD of four experiments. Hepatocytes were cultured for $24 \mathrm{~h}$ with test substances before adding $\left[{ }^{14} \mathrm{C}\right]$ orotic acid.

albumin has been indicated as a negative acute-phase reactant $(21,23)$. However, the precise molecular mechanism for the reduction of albumin synthesis has still not been completely elucidated. Nevertheless, a number of factors have been suggested to play an important role in the regulation of liver synthesis of acute phase proteins, such as hormones, fibrinogen-, or fibrin degradation products, and monocytic products, including IL-1 $(15,25,26)$. From our previous studies $(7,25,26)$ and other investigations (data not shown) we have demonstrated that corticosteroids, growth hormone, insulin, adrenaline, fibrinogen, and fibrin degradation products cannot be implicated in modulating the hepatic synthesis of albumin during the acute-phase response, because administration of these hormones in vivo in rats or in vitro in experiments using primary cultures of rat hepatocytes did not lead to a reduced synthesis of albumin, although in other studies, the fibrinogen synthesis in rats could be stimulated by in vivo administration of fibrinogen or fibrin degradation products (26).

In our present study, we demonstrate that monocytic products reduce the hepatocytic albumin mRNA content in vivo and in vitro. Because the orotic acid incorporation into total RNA was unchanged (Fig. 5) and there was a stable RNA content, the level of albumin mRNA must be affected specifically by the monocytic products and not because of a decreased RNA synthesis or level in general. In fact the level of mRNAs of acutephase protein was increased under this condition (data not shown). The effect of monocytic products on the albumin synthesis and secretion of hepatocytes in vitro is augmented in the presence of $1 \mu \mathrm{M}$ dexamethasone. The role of dexamethasone on albumin secretion and the content of albumin mRNA in hepatocytes in vitro has been discussed previously (7). The lack of a significant decrease of serum albumin level in rats after administration of monocytic products (data not shown) is due to the masking effect of a relatively long half-life of serum albumin in the relatively short duration of experiments and the absence of protein loss, as was the case in turpentine injection due to exudation. Nevertheless, reduced albumin synthesis and secretion by hepatocytes can be clearly observed in primary cultures after the addition of monocytic products (Fig. 4). In contrast, the synthesis and secretion of total protein in vitro is not affected by the monocytic products (data not shown). Although in these experiments we did not utilize a specific purified product of macrophages, the results of experiments in vivo in rats after turpentine injection or administration of monocytic products in vivo and in vitro indicate that reduced albumin synthesis under these circumstances can be partially abolished by the administration of specific anti-sera against the 15-kD-mol wt protein of monocytic products. In addition, similar findings have also been obtained in experiments using commercially available purified IL-1. Therefore, we can conclude from these findings, that hypoalbuminemia during the inflammatory reaction can be partially ascribed to a specifically decreased synthesis of albumin in the liver as the result of monocytic (macrophagic) products, including IL-1.

\section{Acknowledgments}

This work was supported in part by a grant from the Foundation for Fundamental Medical Research (MEDIGON).

\section{References}

1. van Tongeren, J. H. M., O. J. J. Cluysenaar, C. B. H. Lamers, P. H. M. de Mulder, and S. H. Yap. 1978. Causes of hypoalbuminaemia. In Clinical Aspects of Albumin. S. H. Yap, C. L. H. Majoor, J. H. M. van Tongeren, editors. Martinus Nijhoff Publishing Co., The Hague, Netherlands. 117-133.

2. Yap, S. H., J. C. M. Hafkenscheid, and J. H. M. van Tongeren. 1974. Rate of synthesis of albumin in relation to serum levels of essential amino acids in patients with bacterial overgrowth in the small bowel. Eur. J. Clin. Invest. 4:279-284.

3. McFarlane, A. S. 1956. Labelling of plasma proteins with radioactive iodine. Biochem. J. 62:135-143.

4. McFarlane, A. S. 1963. Measurements of synthesis rates of liver produced plasma proteins. Biochem. J. 89:277-290.

5. Hafkenscheid, J. C. M., S. H. Yap, and J. H. M. van Tongeren. 1973. Measurement of the rate of synthesis of albumin with ${ }^{14} \mathrm{C}$-carbonate. A simplified method. Z. Klin. Chem. Klin. Biochem. 11:147-151.

6. Seglen, P. O. 1976. Preparation of isolated rat liver cells. In Methods of Cellular Biology. D. M. Prescott, editor. Academic Press, New York. 29-83.

7. Moshage, H. J., H. J. W. de Haard, H. M. G. Princen, and S. H. Yap. 1985. The influence of glucocorticoid on albumin synthesis and its messenger RNA in rat in vivo and in hepatocyte suspension culture. Biochim. Biophys. Acta. 824:27-33.

8. Princen, J. M. G., G. P. B. M. Mol-Backx, and S. H. Yap. 1981. Acute effects of ethanol intake on albumin and total protein synthesis in free and membrane-bound polyribosomes of rat liver. Biochim. Biophys. Acta. 655:119-127.

9. Crane, L. J., and D. L. Miller. 1975. A solid-phase radioimmunoassay for fibrinogen. Anal. Biochem. 64:60-67.

10. Kapuscinski, J., and B. Skoczylas. 1977. Simple and rapid fluorimetric method for DNA microassay. Anal. Biochem. 83:252-257.

11. Taylor, J. M., and R. T. Schimke. 1973. Synthesis of rat liver albumin in a rabbit reticulocyte cell-free protein-synthesizing system. $J$. Biol. Chem. 248:7661-7668.

12. Yap, S. H., R. K. Strair, and D. A. Shafritz. 1978. Effect of a 
short term fast on the distribution of the cytoplasmic albumin messenger ribonucleic acid in rat liver. J. Biol. Chem. 253:4944-4950.

13. Princen, H. M. G., G. C. M. Selten, A. M. E. Selten-Versteegen, G. P. B. M. Mol-Backx, W. Nieuwenhuizen, and S. H. Yap. 1982. Distribution of mRNAs of fibrinogen polypeptides and albumin in free and membrane-bound polyribosomes and induction of $\alpha$-fetoprotein mRNA synthesis during liver regeneration after partial hepatectomy. Biochim. Biophys. Acta. 699:121-130.

14. Selten, G. C. M., H. M. G. Princen, A. M. E. Selten-Versteegen, G. P. B. M. Mol-Backx, and S. H. Yap. 1982. Sequence content of $\alpha$ fetoprotein, albumin and fibrinogen polypeptide mRNAs in different organs, developing tissues and in liver during carcinogenesis in rats. Biochim. Biophys. Acta. 699:131-137.

15. Ritchie, D. G., and G. M. Fuller. 1981. An in vitro bioassay for leukocytic endogenous mediator(s) using cultured rat hepatocytes. Inflammation. 5:275-287.

16. Dinarello, C. A., L. Renfer, and S. M. Wolff. 1977. Human leukocytic pyrogen: purification and development of a radioimmunoassay. Proc. Natl. Acad. Sci. USA. 74:4624-4627.

17. Gery, I., R. K. Gershon, and B. H. Waksman. 1972. Potentiation of the T-lymphocyte response to mitogens I. The responding cell. J. Exp. Med. 136:128-142.

18. Aviv, H., and P. Leder. 1972. Purification of biologically active globin messenger RNA by chromatography on oligothymidylic acid-cellulose. Proc. Natl. Acad. Sci. USA. 69:1408-1412.
19. Marcu, K., and B. Dudock. 1974. Characterization of a highly efficient protein synthesizing system, derived from commercial wheat germ. Nucleic Acids Res. 1:1386-1394.

20. Laemmli, U. K. 1970. Cleavage of structural proteins during the assembly of the head of bacteriophage T4. Nature (Lond.). 227:680-685.

21. Princen, J. M. G., W. Nieuwenhuizen, G. P. B. M. Mol-Backx, and S. H. Yap. 1981. Direct evidence of transcriptional control of fibrinogen and albumin synthesis in rat liver during the acute phase. Biochem. Biophys. Res. Commun. 102:717-723.

22. Dinarello, C. A. 1984. Interleukin-I. Rev. Infect. Dis. 6:51-95.

23. Bornstein, D. L. 1982. Leukocytic pyrogen: a major mediator of the acute phase reaction. Ann. N. Y. Acad. Sci. 389:323-337.

24. Yap, S. H., J. C. M. Hafkenscheid, C. M. I. C. Goossens, W. C. A. M. Buys, R. A. Binkhorst, and J. H. M. van Tongeren. 1975. Estimation of radiation dosage and transmutation effect of ${ }^{14} \mathrm{C}$ involved in measuring rate of albumin synthesis with ${ }^{14} \mathrm{C}$-carbonate. J. Nucl. Med. 16:642-648.

25. Princen, H. M. G., H. J. Moshage, H. J. W. de Haard, P. J. L. van Gemert, and S. H. Yap. 1984. The influence of glucocorticoid on the fibrinogen messenger RNA content of rat liver in vivo and in hepatocyte suspension culture. Biochem. J. 220:631-637.

26. Princen, H. M. G., H. J. Moshage, J. J. Emeis, H. J. W. de Haard, W. Nieuwenhuizen, and S. H. Yap. 1985. Fibrinogen fragments X, Y, $D$ and $E$ increase levels of plasma fibrinogen and liver mRNA's coding for fibrinogen polypeptides in rats. Thromb. Hemostasis. 53:212-215. 